\title{
Pendampingan 1000 Hari Pertama Kehidupan Pada Ibu Hamil Di Wilayah Kecamatan Cimahi Selatan
}

\author{
Evi Sovia, Anastasia Yani Triningtias \\ Fakultas Kedokteran, Universitas Jenderal Achmad Yani \\ Email: soviaevi@yahoo.com
}

\begin{abstract}
ABSTRAK
Masa 1000 hari pertama kehidupan (HPK) merupakan masa terpenting dalam daur kehidupan manusia. Pengabdian kepada masyarakat (PKM) ini bertujuan untuk mendampingi ibu hamil sampai melahirkan dan anak berusia dua tahun dengan memberikan edukasi dan pemantauan status gizi. PKM ini dilakukan pada 147 ibu hamil di wilayah Kecamatan Cimahi Selatan yang masing-masing didampingi oleh seorang mahasiswa Fakultas Kedokteran Universitas Jenderal Achmad Yani untuk melakukan edukasi dan pemantauan status gizi. Hasil PKM menunjukkan sebagian besar ibu hamil sudah melakukan asuhan antenatal secara teratur ke pelayanan kesehatan, tetapi persalinan ibu dengan usia kehamilan prematur masih cukup tinggi. Penolong persalinan pada umumnya sudah dilakukan oleh tenaga kesehatan. Sebagian besar ibu juga sudah menggunakan kontrasepsi sesudah melahirkan. Berat badan lahir bayi sebagian besar normal dan diberikan ASI ekslusif. Tetapi, masih didapatkan anak dengan status gizi kurang dan tidak mendapatkan imunisasi dasar lengkap. Kesimpulan masih ditemukan masalah gizi dan imunisasi pada bayi sasaran pendampingan $1000 \mathrm{HPK}$.
\end{abstract}

Kata kunci: 1000 HPK, ibu hamil, bayi, status gizi

\begin{abstract}
The first 1000 days of life (FDL) are the most important period in the human life cycle. This community service activity aims to assistance mother during pregnancy until the baby 2 years old given education and nutritional status monitoring. The community service activity was conducted in Cimahi Selatan sub district in 147 pregnant women, each assisted by one medical student of Faculty of Medicine, Universitas Jenderal Achmad Yani. The results showed that most pregnant women had performed Antenatal Care to the health provider regularly, however women with preterm gestational age were still quite high. Delivery assistance in general has been done by health workers. Most of the mothers also used contraception after labor. The baby's birth weight were mostly normal and given exclusive breastfeeding. However, we found children who have nutritional and immunization problem. Conclusions there are still found nutritional and immunization problems in 1000 FDL assistance babies.
\end{abstract}

Keywords: 1000 FDL, pregnant women, babies, nutition status

\section{PENDAHULUAN}

Gerakan "Scaling Up Nutrition (SUN Movement)" merupakan gerakan global di bawah koordinasi Sekretaris Jenderal PBB. Tujuan Global SUN Movement adalah menurunkan masalah gizi, dengan fokus pada 1000 hari pertama kehidupan (270 hari selama kehamilan dan 730 hari dari kelahiran sampai usia 2 tahun) yaitu pada ibu hamil, ibu menyusui dan anak usia 0-23 bulan. Indikator Global SUN Movement adalah penurunan Bayi Berat Lahir Rendah (BBLR), anak balita pendek (stunting), kurus (wasting), gizi kurang (underweight), dan gizi lebih (overweight) (Kementerian Kesehatan RI, 2012).

1000 hari pertama kehidupan (HPK) memengaruhi kesehatan dan kemampuan intelektual. Faktor antenatal seperti antenatal care (ANC), status gizi ibu hamil dan penyakit pada kehamilan mempengaruhi hasil kelahiran pada anak-anak. Anak-anak dari komunitas kumuh perkotaan miskin di negara-negara berkembang memiliki beban morbiditas tinggi terutama penyakit saluran pernapasan dan gastrointestinal dalam dua tahun pertama kehidupan (Kattula et al., 2014).

Sejak tahun 2014, Fakultas Kedokteran Universitas Jenderal Achmad Yani (FK Unjani) sudah melaksanakan modul Pembelajaran Berbasis Komunitas (PBK) yang kegiatannya yaitu melakukan pendampingan kepada ibu hamil sampai melahirkan dan sampai anak berusia 2 
tahun (1000 HPK). Kegiatan selama pendampingan yaitu berbagi informasi tentang $1000 \mathrm{HPK}$. Penyuluhan 1000 HPK berpengaruh terhadap peningkatan pengetahuan ibu(Al Rahmad, 2019) Pendampingan dilakukan semenjak ibu hamil karena gizi ibu selama hamil berdampak terhadap Angka Kematian lbu (AKI) dan Angka Kematian Bayi (AKB) yang merupakan indikator kemajuan kesehatan suatu negara (Husnah, 2017). Program Pendampingan 1000 HPK bertujuan memberdayakan dan berkolaborasi dengan masyarakat dalam upaya meningkatkan derajat kesehatan khususnya ibu hamil, bayi dan balita.

Berdasarkan latar belakang tersebut, pengabdian kepada masyarakat ini bertujuan untuk mengetahui hasil pendampingan 1000 HPK mahasiswa angkatan 2014 Modul PBK Fakultas Kedokteran Unjani.

\section{BAHAN DAN METODE}

Pengabdian kepada masyarakat ini dilakukan terhadap 147 ibu hamil di Kecamatan Cimahi Selatan. Kegiatan berupa pendampingan ibu hamil sampai melahirkan dan bayi berusia 2 tahun. Pendampingan dilakukan oleh mahasiswa Fakultas Kedokteran Universitas Jenderal Achmad Yani (FK Unjani) untuk masing-masing ibu hamil. Mahasiswa melakukan kunjungan rumah setiap bulan untuk memberikan edukasi dan memantau status gizi. Edukasi yang diberikan meliputi kesehatan pada ibu hamil, ibu bersalin dan ibu menyusui, kontrasepsi, pemberian ASI ekslusif, dan imunisasi. Pemantauan status gizi dilakukan dengan mengukur berat badan dan tinggi badan bayi. Kegiatan ini merupakan bagian dari proses belajar mengajar yang dilaksanakan pada tahap sarjana kedokteran.

\section{HASIL}

Karakteristik Ibu

Sebagian besar ibu hamil sudah melakukan asuhan antenatal lebih dari 4 kali (92,6\%), dan lebih dari setengahnya melakukan asuhan antenatal di bidan swasta (52,3\%) (Tabel 1). Pada saat bersalin, ibu dengan usia kehamilan prematur masih cukup tinggi (25,5\%), tempat bersalin sebagian besar di bidan (44,3\%). Penolong persalinan pada umumnya sudah dilakukan oleh tenaga kesehatan (96\%) tetapi masih ada ibu sasaran yang bersalin di paraji $(2,7 \%)$ (Tabel 2). Tempat bersalin sebagian besar di bidan (44,3\%), tetapi masih ada ibu sasaran yang melakukan persalinan di rumah sendiri (4\%). Penolong persalinan pada umumnya sudah dilakukan oleh tenaga kesehatan $(97,3 \%)$ tetapi masih ada ibu yang bersalin di paraji (dukun bayi) $(2,7 \%)$.

Ibu yang menggunakan kontrasepsi yaitu $88,6 \%$, dengan metode terbanyak yaitu pil $(32,2 \%) \quad$ (Tabel 3). Alasan ibu yang tidak menggunakan kontrasepsi diantaranya yaitu masih ingin mempunyai anak, dilarang suami, tidak ingin memakai kontrasepsi, takut efek samping, dan tidak nyaman.

\section{Karakteristik bayi}

Sebagian besar berat badan lahir bayi $>2500 \mathrm{~g}(94 \%)$, dilakukan inisiasi meyusui dini $(75,8 \%)$ dan mendapatkan ASI ekslusif (79,9\%). Status gizi di akhir masa pendampingan terdapat $11,4 \%$ anak sasaran yang mempunyai status gizi kurang, 10,1\% stunting dan $8,1 \%$ kurus. Hasil status imunisasi didapatkan $6 \%$ anak sasaran tidak mendapatkan imunisasi dasar lengkap. Perkembangan anak sasaran hampir seluruhnya sesuai dengan usia (99,3\%). Anak sasaran yang mendapat vitamin A sebanyak 94,7\% (Tabel 4).

\section{PEMBAHASAN}

Asuhan antenatal yaitu perawatan yang diberikan oleh profesional kesehatan yang terampil kepada wanita hamil dan remaja perempuan untuk memastikan kondisi kesehatan terbaik untuk ibu dan bayi selama kehamilan. Komponen asuhan antenatal meliputi: identifikasi risiko; pencegahan dan manajemen penyakit yang berhubungan dengan kehamilan; pendidikan kesehatan dan promosi kesehatan. Tujuan asuhan antenatal adalah untuk memantau keselamatan dan kesejahteraan ibu dan janin. Frekwensi asuhan antenatal yang dianjurkan oleh WHO adalah 4 kali selama masa kehamilan, yaitu satu kali pada trimester pertama, satu kali 
pada trimester kedua, dan dua kali pada trimester ketiga (WHO, 2009; WHO, 2016). Ibu hamil yang didampingi sebagian besar sudah baik dengan melakukan asuhan antenatal minimal 4 kali di pelayanan kesehatan. Salah satu faktor yang berhubungan dengan frekuensi kunjungan asuhan antenatal adalah paritas, ibu multipara dan grandemultipara cenderung tidak melakukan asuhan antenatal karena merasa sudah berpengalaman (Aisyah et al., 2015). Keteraturan kunjungan asuhan antenatal juga sangat diperlukan karena keteraturan kunjungan asuhan antenatal dan kepatuhan konsumsi tablet Fe berhubungan dengan kejadian anemia pada ibu hamil trimester III (Nurmasari \& Sumarmi, 2019).

Usia ibu menjadi faktor yang paling dominan terhadap persalinan preterm. Secara fisik alat reproduki pada usia $<20$ tahun belum terbentuk sempurna, pada umumnya rahim masih relatif kecil karena pembentukan belum sempurna dan pertumbuhan tulang panggul belum belum cukup lebar. Pada usia $<20$ tahun kondisi ibu juga masih dalam tahap pertumbuhan sehingga masukan makanan banyak dipakai untuk ibu sehingga mengakibatkan gangguan pertumbuhan janin. Sedangkan pada usia $>35$ tahun risiko terjadinya komplikasi kehamilan juga meningkat yang berdampak pada morbiditas dan mortalitas bayi yang akan dilahirkan (Wahyuni \& Rohani, 2017).

Adanya ibu yang melakukan persalinan di rumah kemungkinan karena kenyamanan dan kebiasaan keluarga yang sudah berlangsung, merasa kurang nyaman dan tidak praktis melahirkan di fasilitas kesehatan, sedangkan jarak tidak menjadi masalah dalam persalinan di fasilitas kesehatan (Nurasih \& Nurrochmi, 2017). Ibu lebih memilih dukun bayi sebagai penolong persalinan karena percaya dukun bayi lebih berpengalaman dalam menolong persalinan, dukun bayi juga dinilai lebih perhatian dan sabar dalam melayani pasiennya. Pemilihan dukun bayi sebagai penolong persalinan berkaitan dengan pelayanan yang diberikan dan kepercayaan masyarakat itu sendiri (Nurhidayanti, Margawati, \& Irene, 2018).

Pemilihan metode kontrasepsi berhubungan dengan pengetahuan, sikap, dukungan petugas KB, dan ketersediaan pelayanan KB (Setiasih, Widjanarko, \& Istiarti, 2016). Ibu yang menggunakan metode kontrasepsi jangka panjang (sterilisasi, IUD, dan Implant) hanya 25,6\%. Variabel yang paling berpengaruh terhadap pemilihan metode kontrasepsi jangka panjang adalah adalah sikap (Setiasih et al., 2016). Tingkat pendidikan memiliki hubungan yang bermakna dengan pemilihan kontrasepsi, seseorang dengan tingkat pendidikan tinggi cenderung memilih kontrasepsi IUD (Jurisman, Ariadi, \& Kurniati, 2016). Ibu yang menggunakan kontrasepsi KB suntik adalah 44 orang $(29,5 \%)$. Faktor usia signifikan mempengaruhi tingginya akseptor KB suntik 3 bulan. Umur reproduktif dapat memengaruhi penggunaan kontrasepsi suntik dikarenakan dianggap memiliki efektivitas dan kemudahan (Septianingrum, Wardani, Kartini, Keperawatan, \& Keperawatan, 2018).

Berat badan lahir bayi sasaran sebagian besar normal yaitu $>2500 \mathrm{~g}(94 \%)$, faktor yang paling memengaruhi berat badan lahir adalah berat badan prahamil ibu. Ibu dengan berat badan prahamil kurang dari $50 \mathrm{~kg}$ berisiko 6,64 kali lebih besar untuk melahirkan bayi dengan berat badan lahir kurang dari 3000g (Karima \& Achadi, 2012). Terdapat bayi dengan berat badan < $2000 \mathrm{~g}$ atau berat badan lahir rendah (BBLR). Bayi BBLR berisiko untuk terjadinya ikterus (Latifah, Nirmala, \& Astuti, 2017). Sedangkan faktor risiko yang paling berpengaruh terhadap kejadian BBLR adalah anemia pada ibu hamil dan paritas ibu (Mahayana, Chundrayetti, \& Yulistini, 2015). Jumlah ibu yang melakukan inisiasi meyusui dini (IMD) yaitu $75,8 \%$. Salah satu manfaat IMD adalah dapat mengurangi risiko kehilangan panas pada bayi baru lahir (Hutagaol, Darwin, \& Yantri, 2014). Pelaksanaan IMD dipengaruhi oleh pendidikan, pengetahuan, sikap, tindakan bidan, dan dukungan keluarga (Sirajuddin et al., 2013). Sedangkan bayi yang mendapatkan ASI ekslusif adalah 79,9\%, angka ini lebih besar dibandingkan cakupan ASI ekslusif di Jawa Barat pada tahun 2017 yaitu 38,23\% (Data dan Informasi Profil Kesehatan Indonesia 2017, 2018). Pemberian ASI eksklusif selama periode $1000 \mathrm{HPK}$, memengaruhi perkembangan motorik (Hanim \& Salimo, 2018). Salah satu faktor yang berhubungan dengan pamberian ASI eksklusif adalah peran keluarga (Destyana, Angkasa, \& Nuzrina, 2018).

Terdapat $11,4 \%$ anak sasaran yang mempunyai status gizi kurang, 10,1\% stunting dan $8,1 \%$ kurus. Status gizi berhubungan dengan pendidikan ibu, pekerjaan ibu, pendapatan 
keluarga, jumlah anak dan pola asuh ibu (Putri, Sulastri, \& Lestari, 2015). Anak sasaran pendampingan yang sudah mendapatkan imunisasi dasar lengkap yaitu $94 \%$, sedangkan $6 \%$ anak sasaran tidak mendapatkan imunisasi dasar lengkap (IDL). Imunisasi adalah proses merangsang sistem kekebalan tubuh dengan cara memasukkan suatu virus atau bakteri. Sebelum diberikan, virus atau bakteri tersebut telah dilemahkan atau dibunuh. Program imunisasi bertujuan untuk menurunkan angka kesakitan dan kematian dari penyakit yang dapat dicegah dengan imunisasi. IDL terdiri dari BCG, DPT, Hepatitis B, Polio, HiB (Hemophilus Influenzae type B) dan Campak (Yuniarto, 2010). Demikian juga dengan perkembangan anak, sasaran hampir seluruhnya sesuai dengan usia (99,3\%).

Bayi yang mendapat vitamin A sebanyak $94,7 \%$. Vitamin A berperan terhadap fungsi kekebalan tubuh (imunitas) manusia. Terjadinya defisiensi vitamin A menyebabkan mekanisme protektif spesifik dan non spesifik rusak, yaitu respon humoral terhadap bakteri, imunitas mukosal, aktivitas sel NK dan phagositosis. Selain itu, defisiensi vitamin ini berakibat pada meningkatnya resiko penyakit infeksi, seperti campak, diare, ISPA dan malaria. Suplementasi vitamin A dapat menurunkan morbiditas dan mortalitas karena penyakit campak dan diare, juga dapat menurunkan morbiditas malaria Plasmodium falciparum dan morbiditas serta mortalitas ibu saat hamil (Azrimaidaliza, 2007).

\section{KESIMPULAN DAN SARAN}

Hasil pendampingan 1000 Hari Pertama Kehidupan yaitu sebagian besar ibu hamil sudah melakukan ANC ke pelayanan kesehatan dengan kuantitas yang cukup. Ibu bersalin sebagian besar melakukan persalinan di pelayanan kesehatan dan melakukan IMD. Pemberian ASI ekslusif masih harus ditingkatkan, demikian juga dengan keikutsertaan dalam program KB. Pada anak sasaran masih ditemukan masalah gizi dan IDL yang tidak lengkap. Sedangkan perkembangan anak sasaran pada umumnya sudah sesuai dengan usianya. Penulis menyarankan supaya kegiatan pendampingan tetap dilanjutkan supaya tidak ada lagi masalah gizi di masyarakat.

\section{UCAPAN TERIMA KASIH}

Ucapan terimakasih disampaikan kepada seluruh mahasiswa Fakultas Kedokteran Unjani Angkatan 2014 yang telah melakukan pendampingan dan dosen pembimbing Pembelajaran Berbasis Komunitas FK Unjani.

\section{DAFTAR PUSTAKA}

Aisyah, R. D., Rusmariana, A., Mujiati, D., Muhammadiyah, S., Pekalongan, P., Raya, J., \& No, A. (2015). Frekuensi Kunjungan ANC ( Antenatal Care ) Pada lbu Hamil Trimester III. Jurnal IImiah Kesehatan, VIII(2).

Al Rahmad, A. H. (2019). Pengaruh Penyuluhan 1000 Hari Pertama Kehidupan ( HPK ) pada Pasangan Usia Subur di Perkotaan dan Perdesaan. Jurnal Kesehatan, 10(1), 147-152.

Azrimaidaliza. (2007). Vitamin A, Imunitas Dan Kaitannya Dengan Penyakit Infeksi. Jurnal Kesehatan Masyarakat, 1(2), 90-96.

Data dan Informasi Profil Kesehatan Indonesia 2017. (2018).

Destyana, R., Angkasa, D., \& Nuzrina, R. (2018). Hubungan Peran Keluarga dan Pengetahuan Ibu Terhadap Pemberian ASI diDesa Tanah Merah Kabupaten Tangerang. Indonesian Journal of Human Nutrition, 5(1), 1-10.

Hanim, D., \& Salimo, H. (2018). Hubungan Pemberian ASI Eksklusif, Status Gizi, dan Kejadian Diare dengan Perkembangan Motorik pada 1000 Hari Pertama Kehidupan. Sari Pediatri, 20(2), 70-78.

Husnah. (2017). Nutrisi Pada 1000 Hari Pertama Kehidupan. Jurnal Kedokteran Syiah 
Kuala, 17(3), 179-183.

Hutagaol, H. S., Darwin, E., \& Yantri, E. (2014). Pengaruh Inisiasi Menyusu Dini ( IMD ) terhadap Suhu dan Kehilangan Panas pada Bayi Baru Lahir. Jurnal Kesehatan, 3(3), 332-338.

Jurisman, A., Ariadi, \& Kurniati, R. (2016). Hubungan Karakteristik Ibu dengan Pemilihan Kontrasepsi di Puskesmas Padang Pasir Padang. Jurnal Kesehatan Andalas, 5(1), 191-195.

Karima, K., \& Achadi, E. L. (2012). Status Gizi Ibu dan Berat Badan Lahir Bayi. Jurnal Kesehatan Masyarakat Nasional, 7(3), 111-119.

Kattula, D., Sarkar, R., Sivarathinaswamy, P., Velusamy, V., Venugopal, S., Naumova, E. N., ... Kang, G. (2014). The first 1000 days of life: Prenatal and postnatal risk factors for morbidity and growth in a birth cohort in southern India. BMJ Open, 4(7). http://doi.org/10.1136/bmjopen-2014-005404

Kementerian Kesehatan RI. (2012). Pedoman Perencanaan Program Gerakan Nasional Percepatan Perbaikan Gizi dalam Rangka 1000 HPK. Gerakan Nasional Percepatan Perbaikan Gizi dalam Rangka Seribu Hari Pertama Kehidupan (Gerakan 100 HPK).

Latifah, L., Nirmala, S. A., \& Astuti, S. (2017). Hubungan Antara Bayi Berat Lahir Rendah dengan Kejadian Ikterus di Rumah Sakit Umum Daerah Soreang Periode JanuariDesember Tahun 2015. Jurnal Bidan “Midwife Journal," 3(02), 13-21.

Mahayana, S. A. S., Chundrayetti, E., \& Yulistini. (2015). Faktor Risiko yang Berpengaruh terhadap Kejadian Berat. Jurnal Kesehatan Andalas, 4(3), 664-673.

Nurasih, \& Nurrochmi, E. (2017). Analisis Alasan Memilih Bersalin di Rumah di Wilayah Kerja Puskesmas Sitopeng Kota Cirebon Tahun 2016. Jurnal Care, 5(3), 345-358.

Nurhidayanti, S., Margawati, A., \& Irene, M. (2018). Kepercayaan Masyarakat terhadap Penolong Persalinan di Wilayah Halmahera Utara. Jurnal Promosi Kesehatan Indonesia, 13(1), 46-60.

Nurmasari, V., \& Sumarmi, S. (2019). Hubungan Keteraturan Kunjungan Antenatal Care dan Kepatuhan Konsumsi Tablet Fe dengan Kejadian Anemia pada Ibu Hamil Trimester III di Kecamatan Maron Probolinggo Relation between Regularity of Antenatal Care Visits and Compliance of Iron Tablets Consumpti. Amerta Nutr, 4651. http://doi.org/10.20473/amnt.v3.i1.2019.46-51

Putri, R. F., Sulastri, D., \& Lestari, Y. (2015). Faktor-Faktor yang Berhubungan dengan Status Gizi Anak Balita di Wilayah Kerja Puskesmas Nanggalo Padang. Jurnal Kesehatan Andalas, 4(1), 254-261.

Septianingrum, Y., Wardani, E. M., Kartini, Y., Keperawatan, P. S., \& Keperawatan, F. (2018). Faktor-faktor yang Mempengaruhi Tingginya Akseptor KB Suntik 3 Bulan. Jurnal Ners Dan Kebidanan, 5(1), 15-19. http://doi.org/10.26699/jnk.v5i1.ART.p015

Setiasih, S., Widjanarko, B., \& Istiarti, T. (2016). Analisis Faktor-faktor yang Mempengaruhi Pemilihan Metode Kontrasepsi Jangka Panjang ( MKIP) pada Wanita Pasangan Usia Subur ( PUS ) di Kabupaten Kendal Tahun 2013. Jurnal Promosi Kesehatan Indonesia, 11(2), 32-46.

Sirajuddin, S., Abdullah, T., Lumula, S. N., Studi, P., Fakultas, G., Masyarakat, K., ... Boalemo, K. (2013). Determinan Pelaksanaan Inisiasi Menyusui Dini. Jurnal Kesehatan Masyarakat Nasional, 8(3), 99-103.

Wahyuni, R., \& Rohani, S. (2017). Faktor-faktor yang Mempengaruhi Persalinan Preterm. Aisyah: Jurnal Ilmu Kesehatan, 2(1), 61-68.

WHO. (2009). WHO Recommended Interventions for Improving Maternal and Newborn Health.

WHO. (2016). WHO recommendations on antenatal care for a positive pregnancy 
experience.

Yuniarto, P. (2010). Pentingnya Imunisasi bagi Anak. BALABA, 6(01), 28-29. 


\section{LAMPIRAN}

Tabel 1. Frekwensi dan Tempat Pelaksanaan Asuhan Antenatal

\begin{tabular}{ll}
\hline Frekwensi ANC & Jumlah $(\%)$ \\
\hline$<4$ kali & $11(7,4 \%)$ \\
$>4$ kali & $137(92,6 \%)$ \\
Tempat ANC & \\
Puskesmas & $60(40,3 \%)$ \\
Praktek Bidan Swasta & $77(52,3 \%)$ \\
Praktek Dokter Spesialis & $9(6 \%)$ \\
Rumah Sakit & $1(0,7 \%)$ \\
Paraji & 0 \\
\hline
\end{tabular}

Tabel 2. Usia kehamilan saat bersalin, tempat dan penolong persalinan

\begin{tabular}{ll}
\hline Karakteristik Ibu Bersalin & Jumlah $(\%)$ \\
\hline Usia kehamilan saat bersalin & \\
Prematur & $37(25,5 \%)$ \\
Aterm & $110(74,5 \%)$ \\
Tempat bersalin & \\
Puskesmas & $21(14,1 \%)$ \\
Bidan & $65(44,3 \%)$ \\
Rumah Sakit & $48(32,9 \%)$ \\
Klinik Bersalin & $7(4,7 \%)$ \\
Rumah sendiri & $6(4 \%)$ \\
Penolong persalinan & \\
Dokter & $10(6,7 \%)$ \\
Dokter kandungan & $44(29,5 \%)$ \\
Bidan & $92(61,1 \%)$ \\
Paraji & $4(2,7 \%)$ \\
\hline
\end{tabular}

Tabel 3. Keikutsertaan dalam Program Keluarga Berencana

\begin{tabular}{ll}
\hline Keikutsertaan dalam program KB & Jumlah (\%) \\
\hline Akseptor KB & \\
Ya & $133(88,6 \%)$ \\
Tidak & $14(8,7 \%)$ \\
Metode KB & \\
Sterilisasi & $5(3,4 \%)$ \\
Pil & $48(32,2 \%)$ \\
IUD & $32(21,5 \%)$ \\
Suntik & $44(29,5 \%)$ \\
Implant & $1(0,7 \%)$ \\
Kondom & $1(0,7 \%)$ \\
Coitus Interuptus & $2(1,3 \%)$ \\
\hline
\end{tabular}

Tabel 4. Karakteristik bayi Hasil Pendampingan

\begin{tabular}{ll}
\hline Karakteristik & Jumlah (\%) \\
\hline Berat badan lahir & \\
$<2500 \mathrm{~g}$ & $7(4 \%)$ \\
$>2500 \mathrm{~g}$ & $140(94 \%)$ \\
Inisiasi Menyusui Dini & \\
Ya & $113(75,8 \%)$ \\
Tidak & $34(23,5 \%)$
\end{tabular}


ASI Ekslusif

Ya

$118(79,9 \%)$

Tidak

$29(20,1 \%)$

Status gizi (BB/Umur)

Kurang

$16(11,4 \%)$

Normal

$131(88,6 \%)$

Status gizi (TB/Umur)

Pendek

$14(10,1 \%)$

Normal

$130(87,9 \%)$

Tinggi

Status Gizi (BB/TB)

$3(2 \%)$

Kurus

$11(8,1 \%)$

Normal

$136(91,9 \%)$

Imunisasi Dasar Lengkap

Ya

$138(94 \%)$

Tidak

$9(6 \%)$

Perkembangan anak

Sesuai usia

$146(99,3 \%)$

Tidak sesuai usia

$1(0,7 \%)$

Pemberian vitamin A

Ya

$140(94,7 \%)$

Tidak

$1(0,7 \%)$

Tidak tahu

$6(4,7 \%)$ 